九州大学学術情報リポジトリ

Kyushu University Institutional Repository

\title{
Evaluation of Five Extraction Methods for Available Phosphorus in Intensively Fertilized Greenhouse Soils
}

Than, Aye Aye

Laboratory of Soil Science, Division of Plant Resources, Graduate School of Bioresources and Bioenvironmental Sciences, Kyushu University

Araki, Masato

Fukuoka Agricultural Experimental Station

Wada, Shin-ichiro

Laboratory of Soil Science, Division of Bioproduction Environmental Sciences, Department of Agro-environmental Sciences, Faculty of Agriculture, Kyushu University

https://doi.org/10.5109/19534

出版情報: 九州大学大学院農学研究院紀要. 56 (1)，pp.87-92，2011-02. Faculty of Agriculture， Kyushu University

バージョン :

権利関係 : 


\title{
Evaluation of Five Extraction Methods for Available Phosphorus in Intensively Fertilized Greenhouse Soils
}

\author{
Than AYE AYE ${ }^{1}$, Masato ARAKI ${ }^{2}$ and Shin-Ichiro WADA* \\ Laboratory of Soil Science, Division of Bioproduction Environmental Sciences, \\ Department of Agro-environmental Sciences, Faculty of Agriculture, \\ Kyushu University, Fukuoka 812-8581, Japan \\ (Received October 29, 2010 and accepted November 8, 2010)
}

\begin{abstract}
Intensively fertilized lime receiving soils encased in greenhouses have complex nature. We collected 11 greenhouse soils and examined the chemical forms of inorganic phosphorus (P) by applying two kinds of sequential extraction methods. The results and the foregoing study on the same soils revealed that the method developed for calcareous soils is better suited for the greenhouse soils. Among the five availability testing methods including Truog method, Mehlich III method, Olsen method, water extraction and $\mathrm{CaCl}_{2}$ extraction, the Truog and the Mehlich III methods gave good estimates for calcium phosphate minerals like dicalcium phosphate and octacalcim phosphate. In view of simplicity of the method, Truog method is considered to be the best method for P-enriched greenhouse soils.
\end{abstract}

\section{INTRODUCTION}

Phosphorus (P) is one of the most important nutrients in crop production. Crops uptake $\mathrm{P}$ in abundance but its supply from natural soils is not sufficient. Large amount of synthetic P fertilizers are applied annually to meet $\mathrm{P}$ requirement of crops. Since $\mathrm{P}$ is very reactive with soil minerals particularly with oxide and hydroxide minerals, substantial amount of P is adsorbed by some soil minerals and turned unavailable for crops. Farmers tend to apply excessive amount of $\mathrm{P}$ fertilizers in fear for $\mathrm{P}$ deficiency. The fixation of $\mathrm{P}$ by soil minerals makes it difficult to estimate the amount of available $\mathrm{P}$ in soils. For these reasons, enormous amount of $\mathrm{P}$ accumulates in intensively cultivated greenhouse soils.

In recent years, reflecting the rapid growth of agricultural production and increased fertilizer use in Asia, the depletion of phosphate rock resources has been receiving increasing interest. The fear for possible shortage of $\mathrm{P}$ resources induced a surge of $\mathrm{P}$-fertilizer price in 2008. To avoid excessive application and economize P-fertilizers, reliable test methods for assessing available $\mathrm{P}$ in soils are indispensable. Traditionally simple extraction methods like dilute $\mathrm{H}_{2} \mathrm{SO}_{4}-, \mathrm{NH}_{4} \mathrm{~F}-$ and $\mathrm{NaHCO}_{3}$ extraction have been used to evaluate availability of $\mathrm{P}$ in soils (Olsen and Sommers, 1982; Kuo, 1996) and found to be useful.

Many researches have been focusing on the development of more reliable soil testing method for available P. One of the major shortcomings of the traditional testing methods, i. e. the chemical extraction (Thomas and Peaslee, 1973; Olsen and Sommers, 1982), is that the chemical conditions during $\mathrm{P}$-extraction are not necessarily like those prevailing in the field soil. In addition,

\footnotetext{
1 Laboratory of Soil Science, Division of Plant Resources, Graduate School of Bioresources and Bioenvironmental Sciences, Kyushu University

Fukuoka Agricultural Experimental Station

* Corresponding author (wadasi@agr.kyushu-u.ac.jp)
}

slow diffusion process toward plant roots through interstitial pores cannot be evaluated. To overcome these drawbacks, van der Zee et al. (1987) proposed to use a filter paper that was impregnated with iron oxides and hydroxides (Pi-paper). Most commonly, a piece of the $\mathrm{Pi}$-paper is immersed in a soil suspension for a certain period of time (Van der Zee, 1987). The iron oxide that strongly adsorbs dissolved phosphate ions acts as a $\mathrm{P}-$ sink and keeps the solution $\mathrm{P}$ concentration low, resulting in the enhanced dissolution of sparingly soluble $\mathrm{P}$-compounds and desorption of adsorbed P. Thus, the amount of P extracted by the Pi-paper can be used as a conservative estimate for available $\mathrm{P}$. The $\mathrm{Pi}$-paper has also been used to study $\mathrm{P}$ diffusion by embedding a piece of Pi-paper in a soil column or in situ for a certain period of time (Menon et al., 1990; Saarela, 1992). With these techniques, the availability of soil $\mathrm{P}$ can be evaluated considering both adsorption-desorption plus dissolution-precipitation and diffusion. A testing method based on the similar principle had also developed (Davison and Zhang, 1994) and applied to soil-P testing (Menzies et al., 2005).

Nevertheless, the chemical extraction methods are still useful in that they can extract potentially available $\mathrm{P}$ fraction if the extracting chemicals are suitable for major chemical forms of $\mathrm{P}$ contributed to $\mathrm{P}$ availability in target soils. For example the extraction with $\mathrm{NH}_{4} \mathrm{~F}$ is believed to give a good measure for available $\mathrm{P}$ in acid soils where $\mathrm{P}$ is mostly retained on oxides and hydroxides of $\mathrm{Al}$ and $\mathrm{Fe}$. On the other hand $\mathrm{NaHCO}_{3}$ extraction is suitable for calcareous soils where Ca phosphates predominate. The Japanese soils encased in greenhouses are not calcareous but not acidic, receiving a lot of lime and other amendments annually. They have intermediate and complex nature with regard to the dynamics of nutrients and the criteria for selecting a suitable extracting reagent for available $\mathrm{P}$ have not been established. The objective of the present study was to identify the major chemical forms of $\mathrm{P}$ in some $\mathrm{P}$-eutrophicated greenhouse soils for better selection of the extracting agent. 
Soils collected in greenhouses were subjected two kinds of sequential extraction to estimate the major chemical forms of P. In addition, five chemical extraction methods were applied and the results were compared.

\section{MATERIALS AND METHODS}

\section{Soil samples}

Soil samples were collected from the Ap horizon in 11 greenhouses for vegetable cultivation in Chikushino, Japan. The Y1, Y2 and Y3 soils had been used for eggplant cultivation at least for 3 years. The Y4 soil had been used for cucumber cultivation for 2 years. Tomato had been cultivated on the Y5 and Y6 soils for three consecutive years. The $\mathrm{Y} 7$ and $\mathrm{Y} 8$ soils had been used for rice paddy for more than ten years and newly encased in greenhouses and tomato was grown once. The Y10 soil had been used for strawberry at least for 10 consecutive years. Welsh onion had been harvested several times a year on the Y11 for 5 years. The Y12 soil had been used for eggplant and tomato cultivation.

The soil samples were air-dried after collection, passed through a $2-\mathrm{mm}$ sieve and stored in polyethylene bags. The major chemical properties that are listed in Table 1 were determined following the methods described by the Editorial Boards of Methods for Soil Environment Analysis (1997) except for those otherwise specified. The total $\mathrm{P}$ content was determined by $\mathrm{Na}_{2} \mathrm{CO}_{3}$ fusion following the procedures described by Olsen and Sommers (1982). The carbonate content was determined by the method proposed by Than et al. (2010). All these analyses were carried out in duplicate and the averaged values were shown.

\section{Sequential fractionation of inorganic $p$}

Two sequential fractionation schemes were applied. One (Method A) is the method developed for calcareous soils (Adhami et al., 2006) and the other (Method B) is the one for noncalcareous soils (Kuo, 1996). Extractants used and procedure were briefly described in Table 2 and Table 3.

\section{Available $\mathbf{P}$ extraction}

So called available $\mathrm{P}$ was evaluated with five methods: Mehlich III (Sims, 2000), Olsen (Kuo, 1966), Truog (Editorial Boards of Methods for Soil Environment Analysis, 1997), $\mathrm{CaCl}_{2}$ extraction (Kuo, 1996). For water extraction, $5 \mathrm{~g}$ of an air-dried soil sample was placed in a plastic bag, mixed with $50 \mathrm{~mL}$ of deionized water and agitated the mixture by scrubbing wet air through an inserted glass tube (Than et al., 2010). A brief description of the procedure is given in Table 4 .

\section{RESULTS AND DISCUSSION}

The soil samples contained about 1400 to nearly $3000 \mathrm{mg} / \mathrm{kg}$ of total $\mathrm{P}$, indicating that they are extremely $\mathrm{P}$-eutrophicated. These data and the history of the soils described in the materials and methods section suggests that the intensive fertilization after the soils were encased in greenhouses caused the $\mathrm{P}$ accumulation. The soil $\mathrm{pH}$ ranged from about 6.2 to 6.9 and the soils are nearly neutral. Some soils (Y3, Y4 and Y12) contained appreciable amounts of carbonate but the soil $\mathrm{pH}$ indicates that the soils are noncalcareous in nature. Than et al. (2009) concluded that the conventional procedure for soil $\mathrm{pH}$ measurement is not adequate for some greenhouse soils by showing that the measured $\mathrm{pH}$ value gradually approach 8 when the soil contained significant amount of carbonate $\left(>10 \mathrm{cmol} \mathrm{\textrm {kg } ^ { - 1 }}\right)$. The carbonate contents of the present soil samples are mostly $<1 \mathrm{cmol} \mathrm{kg}^{-1}$ and there would be no problem in the measured $\mathrm{pH}$. The electric conductivity values show that there is no serious accumulation of soluble salts.

The results of the sequential fractionations were summarized in Table 5 and Table 6 . The extraction reagents and procedures for method A and B are similar. One important difference is that the extraction step with

Table 1. Selected chemical properties of soil samples used

\begin{tabular}{|c|c|c|c|c|c|c|c|c|c|c|}
\hline \multirow{2}{*}{$\begin{array}{c}\text { Sample } \\
\text { No }\end{array}$} & \multirow{2}{*}{$\mathrm{pH}$} & \multirow{2}{*}{$\mathrm{EC}$} & \multirow{2}{*}{ Organic C } & \multirow{2}{*}{ Total N } & \multicolumn{4}{|c|}{ Exchangeable cations } & \multirow{2}{*}{ Carbonate } & \multirow{2}{*}{ Total P } \\
\hline & & & & & $\mathrm{Ca}$ & $\mathrm{Mg}$ & $\mathrm{K}$ & $\mathrm{Na}$ & & \\
\hline & & $\mathrm{dS} \mathrm{m}^{-1}$ & \multicolumn{2}{|c|}{------- $\mathrm{g} \mathrm{kg}^{-1}$------- } & \multicolumn{4}{|c|}{--------- cmolc kg kg $^{-1}$-------- } & $\mathrm{cmol} \mathrm{kg}^{-1}$ & $m g \mathrm{~kg}^{-1}$ \\
\hline Y1 & 6.29 & 0.41 & 32.1 & 2.4 & 15.1 & 4.2 & 0.9 & 0.5 & 0.61 & 2893 \\
\hline $\mathrm{Y} 2$ & 6.28 & 0.52 & 30.6 & 2.3 & 14.6 & 4.4 & 0.9 & 0.6 & 0.92 & 2552 \\
\hline Y3 & 6.26 & 0.38 & 29.7 & 2.7 & 14.3 & 4.0 & 0.7 & 0.3 & 1.04 & 2779 \\
\hline Y4 & 6.42 & 0.67 & 18.6 & 1.9 & 13.8 & 3.5 & 0.7 & 0.6 & 1.63 & 2073 \\
\hline Y5 & 6.35 & 0.21 & 16.9 & 1.4 & 13.4 & 3.5 & 0.2 & 0.3 & 0.48 & 2273 \\
\hline Y6 & 6.21 & 0.26 & 17.5 & 1.5 & 12.0 & 3.2 & 0.2 & 0.2 & 0.55 & 1901 \\
\hline Y7 & 6.83 & 0.14 & 19.0 & 1.6 & 9.6 & 2.0 & 0.1 & 0.1 & 0.40 & 1408 \\
\hline Y8 & 6.71 & 0.14 & 17.7 & 1.4 & 8.7 & 1.9 & 0.2 & 0.1 & 0.35 & 1367 \\
\hline Y10 & 6.81 & 0.14 & 28.3 & 2.4 & 15.1 & 4.7 & 0.3 & 0.3 & 0.34 & 2366 \\
\hline Y11 & 6.89 & 0.09 & 22.2 & 1.5 & 11.3 & 2.9 & 0.3 & 0.1 & 0.93 & 1701 \\
\hline Y12 & 6.79 & 0.36 & 27.7 & 1.8 & 16.5 & 4.6 & 0.3 & 0.4 & 1.83 & 1925 \\
\hline
\end{tabular}


acidic acetate buffer is missing in method B. This is because the presence of significant amounts of semistable calcium phosphate is not assumed in method B. The total amounts of inorganic P extracted by the two methods are surprisingly similar for all the soil samples but the extracted amounts in the corresponding steps are quite different. Particularly the $\mathrm{Ca}-\mathrm{P}$ fraction by method B nearly doubled that by method A. Accordingly, the estimated amount of calcium phosphate in method $\mathrm{A}$ $\left(=\mathrm{Ca}_{2}-\mathrm{P}+\mathrm{Ca}_{8}-\mathrm{P}+\mathrm{Ca}_{10}-\mathrm{P}\right)$ was 2 to 3 times larger than that in method $\mathrm{B}\left(=\right.$ soluble $\left.\mathrm{P}+\mathrm{Ca}_{10}-\mathrm{P}\right)$. Than et al. (2010) extracted these soil samples successively with

Table 2. Sequential inorganic $\mathrm{P}$ fractionation procedure for method A

\begin{tabular}{|c|c|c|c|}
\hline Step & Fractionation scheme & Typical P froms & Designation \\
\hline 1 & $\begin{array}{l}0.25 \mathrm{M} \mathrm{NaHCO}_{3}, \mathrm{pH} 7.5,1 \mathrm{~h} \text { shaking, } \\
\text { wash twice with ethanol }\end{array}$ & $\begin{array}{l}\mathrm{Ca}\left(\mathrm{H}_{2} \mathrm{PO}_{4}\right)_{2} \\
\mathrm{CaHPO}_{4} \cdot n \mathrm{H}_{2} \mathrm{O}\end{array}$ & $\mathrm{Ca}_{2}-\mathrm{P}$ \\
\hline 2 & $\begin{array}{l}0.5 \mathrm{~mol} \mathrm{~L}^{-1} \mathrm{NH}_{4} \mathrm{OAc}, \mathrm{pH} 4.2,4 \mathrm{~h} \text { standing and } \\
1 \mathrm{~h} \text { shaking, } \\
\text { wash twice with } 1 \mathrm{~mol} \mathrm{~L}^{-1} \mathrm{MgCl}_{2}\end{array}$ & $\mathrm{Ca}_{8} \mathrm{H}_{2}\left(\mathrm{PO}_{4}\right)_{6} \cdot n \mathrm{H}_{2} \mathrm{O}$ & $\mathrm{Ca}_{8}-\mathrm{P}$ \\
\hline 3 & $\begin{array}{l}0.5 \mathrm{~mol} \mathrm{~L}^{-1} \mathrm{NH}_{4} \mathrm{~F}, \mathrm{pH} 8.2,1 \mathrm{~h} \text { shaking, } \\
\text { wash twice with } 1 \mathrm{~mol} \mathrm{~L}^{-1} \mathrm{MgCl}_{2}, \mathrm{pH} 8\end{array}$ & $\begin{array}{l}\text { Surface complex on } \mathrm{Al} \\
\text { hydroxide }\end{array}$ & $\mathrm{Al}-\mathrm{P}$ \\
\hline 4 & $\begin{array}{l}0.1 \mathrm{~mol} \mathrm{~L}^{-1} \mathrm{NaOH}-0.1 \mathrm{~mol} \mathrm{~L}^{-1} \mathrm{Na}_{2} \mathrm{CO}_{3}, 2 \mathrm{~h} \text { shaking, } 16 \mathrm{~h} \\
\text { standing, } 2 \mathrm{~h} \text { shaking, } \\
\quad \text { wash twice with } 1 \mathrm{~mol} \mathrm{~L}^{-1} \mathrm{MgCl}_{2} \text {, pH } 8\end{array}$ & $\begin{array}{l}\text { Surface complex on Fe } \\
\text { hydroxide }\end{array}$ & $\mathrm{Fe}-\mathrm{P}$ \\
\hline 5 & $\begin{array}{l}0.3 \mathrm{~mol} \mathrm{~L}^{-1} \mathrm{Na}_{3} \mathrm{C}_{6} \mathrm{H}_{5} \mathrm{O}_{7}, \mathrm{Na}_{2} \mathrm{~S}_{2} \mathrm{O}_{4}, 0.5 \mathrm{~mol} \mathrm{~L}-1 \mathrm{NaOH}, 17 \mathrm{~h} \\
\text { shaking, } \\
\quad \text { wash twice with } 1 \mathrm{M} \mathrm{MgCl}_{2}, \mathrm{pH} 8\end{array}$ & $\begin{array}{l}\text { Incorporated in } \\
\text { crystalline Fe oxides }\end{array}$ & Occluded P \\
\hline 6 & $0.25 \mathrm{~mol} \mathrm{~L}^{-1} \mathrm{H}_{2} \mathrm{SO}_{4}, 1 \mathrm{~h}$ shaking & $\mathrm{Ca}_{10}\left(\mathrm{PO}_{4}\right)_{6} \cdot(\mathrm{OH})_{2}$ & $\mathrm{Ca}_{10}-\mathrm{P}$ \\
\hline
\end{tabular}

Table 3. Sequential inorganic $P$ fractionation procedure for method B

\begin{tabular}{|c|c|c|c|}
\hline Step & Fractionation scheme & Typical P froms & Designation \\
\hline 1 & $\begin{array}{l}1 \mathrm{~mol} \mathrm{~L}^{-1} \mathrm{NH}_{4} \mathrm{Cl}, \mathrm{pH} 7.5,1 \text { h shaking } \\
\text { wash twice with ethanol }\end{array}$ & $\begin{array}{l}\mathrm{Ca}\left(\mathrm{H}_{2} \mathrm{PO}_{4}\right)_{2} \\
\mathrm{CaHPO}_{4} \cdot n \mathrm{H}_{2} \mathrm{O}\end{array}$ & Soluble-P \\
\hline 2 & $\begin{array}{c}0.5 \mathrm{~mol} \mathrm{~L}^{-1} \mathrm{NH}_{4} \mathrm{~F}, \mathrm{pH} 8.2,1 \mathrm{~h} \text { shaking, } \\
\text { wash twice with } 1 \mathrm{~mol} \mathrm{~L}^{-1} \mathrm{NaCl}\end{array}$ & $\begin{array}{l}\text { Surface complex on } \mathrm{Al} \\
\text { hydroxide }\end{array}$ & $\mathrm{Al}-\mathrm{P}$ \\
\hline 3 & $\begin{array}{l}0.1 \mathrm{~mol} \mathrm{~L}^{-1} \mathrm{NaOH}, 2 \mathrm{~h} \text { shaking, } 16 \mathrm{~h} \text { standing } \\
\text { and } 2 \mathrm{~h} \text { shaking, } \\
\quad \text { wash twice with } 1 \mathrm{~mol} \mathrm{~L}^{-1} \mathrm{NaCl}\end{array}$ & $\begin{array}{l}\text { Surface complex on Fe } \\
\text { hydroxide }\end{array}$ & $\mathrm{Fe}-\mathrm{P}$ \\
\hline 4 & $\begin{array}{l}0.3 \mathrm{~mol} \mathrm{~L}^{-1} \mathrm{Na}_{3} \mathrm{C}_{6} \mathrm{H}_{5} \mathrm{O}_{7}, \mathrm{Na}_{2} \mathrm{~S}_{2} \mathrm{O}_{4}, 0.1 \mathrm{~mol} \mathrm{~L}^{-1} \mathrm{NaHCO}_{3} \text {, } \\
17 \mathrm{~h} \text { shaking, } \\
\quad \text { wash twice with } 1 \mathrm{~mol} \mathrm{~L}^{-1} \mathrm{NaCl}\end{array}$ & $\begin{array}{l}\text { incorporated in } \\
\text { crystalline } \\
\text { Fe oxides }\end{array}$ & Occluded P \\
\hline 5 & $0.5 \mathrm{~mol} \mathrm{~L}^{-1} \mathrm{H}_{2} \mathrm{SO}_{4}, 1 \mathrm{~h}$ shaking & $\mathrm{Ca}_{10}\left(\mathrm{PO}_{4}\right)_{6} \cdot(\mathrm{OH})_{2}$ & $\mathrm{Ca}_{10}-\mathrm{P}$ \\
\hline
\end{tabular}

Table 4. The five extraction methods for available $\mathrm{P}$

\begin{tabular}{|c|c|}
\hline Methods & Extraction procedure \\
\hline Mehlich III & $\begin{array}{l}0.2 \mathrm{~mol} \mathrm{~L}-1 \mathrm{CH}_{3} \mathrm{COOH}-0.25 \mathrm{~mol} \mathrm{~L}-1-\mathrm{NH}_{4} \mathrm{NO}_{3}-0.015 \mathrm{~mol} \mathrm{~L} \mathrm{NH}_{4} \mathrm{~F}, 0.013 \mathrm{~mol} \mathrm{~L}^{-1} \mathrm{HNO}_{3} \text {, } \\
0.001 \mathrm{~mol} \mathrm{~L}^{-1} \mathrm{EDTA}, 5 \text { min shaking, soil : water volumetric ratio }=1: 10\end{array}$ \\
\hline Truog & $1 \mathrm{mmol} \mathrm{L} \mathrm{H}_{2} \mathrm{SO}_{4}, 30$ min shaking, soil : water volumetric ratio = $1: 200$ \\
\hline Olsen & 0.5 mol L ${ }^{-1} \mathrm{NaHCO}_{3} \mathrm{pH} 8.5,30$ min shaking, soil : water volumetric ratio = $1: 20$ \\
\hline Water extraction & Equilibrated under continuous air bubbling for 5 days, soil : water volumetric ratio $=1: 5$ \\
\hline $\mathrm{CaCl}_{2}$ extraction & $0.01 \mathrm{~mol} \mathrm{~L}^{-1} \mathrm{CaCl}_{2}, 1 \mathrm{~h}$ shaking, soil : water volumetric ratio = $1: 10$ \\
\hline
\end{tabular}


Table 5. The amounts of sequentially extracted inorganic $\mathrm{P}$ fractions by method A

\begin{tabular}{|c|c|c|c|c|c|c|c|}
\hline Soil samples & $\mathrm{Ca}_{2}-\mathrm{P}$ & $\mathrm{Ca}_{8}-\mathrm{P}$ & Al-P & Fe-P & Occluded-P & $\mathrm{Ca}_{10}-\mathrm{P}$ & Total \\
\hline & & & & & & & \\
\hline Y1 & 198 & 511 & 866 & 606 & 232 & 155 & 2568 \\
\hline Y2 & 171 & 484 & 773 & 530 & 239 & 138 & 2335 \\
\hline Y3 & 209 & 808 & 551 & 523 & 210 & 155 & 2457 \\
\hline Y4 & 153 & 546 & 403 & 443 & 144 & 111 & 1800 \\
\hline Y5 & 173 & 237 & 696 & 457 & 145 & 108 & 1852 \\
\hline Y6 & 180 & 321 & 498 & 424 & 155 & 154 & 1731 \\
\hline Y7 & 48 & 63 & 546 & 312 & 119 & 101 & 1189 \\
\hline Y8 & 53 & 64 & 490 & 269 & 108 & 87 & 1071 \\
\hline Y10 & 135 & 219 & 464 & 692 & 228 & 158 & 1896 \\
\hline Y11 & 142 & 266 & 497 & 338 & 148 & 73 & 1463 \\
\hline Y12 & 173 & 613 & 345 & 295 & 149 & 104 & 1679 \\
\hline
\end{tabular}

Table 6. The amounts of sequentially extracted inorganic $\mathrm{P}$ fractions by method $\mathrm{B}$

\begin{tabular}{ccccccc}
\hline Soil samples & Soluble-P & Al-P & Fe-P & Occluded-P & Ca $_{10}-\mathrm{P}$ & Total \\
\hline & & & & & & \\
Y1 & 68 & 1203 & 722 & 433 & 134 & 2560 \\
Y2 & 60 & 1039 & 546 & 373 & 101 & 2120 \\
Y3 & 146 & 951 & 666 & 495 & 148 & 2407 \\
Y4 & 119 & 770 & 602 & 362 & 129 & 1982 \\
Y5 & 47 & 1050 & 546 & 248 & 66 & 1957 \\
Y6 & 56 & 810 & 404 & 237 & 95 & 1602 \\
Y7 & 8 & 654 & 298 & 122 & 82 & 1164 \\
Y8 & 11 & 578 & 282 & 109 & 80 & 1059 \\
Y10 & 47 & 685 & 903 & 216 & 89 & 1940 \\
Y11 & 54 & 730 & 382 & 198 & 60 & 1425 \\
Y12 & 153 & 657 & 410 & 344 & 114 & 1677 \\
\hline
\end{tabular}

Table 7. Results of the five extraction methods for available $\mathrm{P}$

\begin{tabular}{cccccc}
\hline \multirow{2}{*}{ samples } & \multicolumn{5}{c}{ Extraction methods } \\
\cline { 2 - 5 } & Mehlich III & Olsen & Troug & Water & $\mathrm{CaCl}_{2}$ \\
\hline Y1 & 735 & 174 & 662 & 20 & 20 \\
Y2 & 631 & 160 & 658 & 14 & 17 \\
Y3 & 904 & 196 & 950 & 44 & 50 \\
Y4 & 713 & 138 & 694 & 18 & 16 \\
Y5 & 577 & 164 & 388 & 21 & 21 \\
Y6 & 575 & 151 & 381 & 21 & 18 \\
Y7 & 180 & 55 & 155 & 3 & 3 \\
Y8 & 195 & 54 & 144 & 3 & 3 \\
Y10 & 482 & 145 & 415 & 21 & 23 \\
Y11 & 597 & 120 & 474 & 34 & 39 \\
Y12 & 641 & 157 & 690 & 28 & 30 \\
\hline
\end{tabular}


$1 \mathrm{~mol} \mathrm{~L}^{-1} \mathrm{NaCl}$ and $0.5 \mathrm{~mol} \mathrm{~L}^{-1} \mathrm{NH}_{4} \mathrm{OAc}$ buffered at $\mathrm{pH} 4.2$ and found large amount of $\mathrm{Ca}$ as well as $\mathrm{P}$ in the second extract. Since exchangeable Ca was removed in the first extraction, simultaneous dissolution of $\mathrm{Ca}$ and $\mathrm{P}$ showed that calcium phosphate dissolved in the second step. The amounts of dissolved P for Y1 to Y12 soils were 688, 634, 922, 646, 474, 431, 158, 173, 396, 385 and $610 \mathrm{mg}$ $\mathrm{kg}^{-1}$ and the $\mathrm{Ca} / \mathrm{P}$ molar ratio ranged from about 1 to 3.5 . They are approximate to the sum of $\mathrm{Ca}_{2}-\mathrm{P}$ and $\mathrm{Ca}_{8}-\mathrm{P}$ in Table 5, indicating that $\mathrm{Ca}_{2}-\mathrm{P}$ and $\mathrm{Ca}_{8}-\mathrm{P}$ fractions actually came from calcium phosphate. On the other hand, these amounts exceed the soluble $\mathrm{P}+\mathrm{Ca}_{10}-\mathrm{P}$ fraction in method B, suggesting that method B is not suitable for the present soil samples. Therefore, only the data from method A are used in the following discussion.

Table 7 shows the results of the five extraction methods for available $\mathrm{P}$. The amounts of $\mathrm{P}$ extracted by Mehlich III method and Truog method were similar to each other and much higher than those by other methods. The comparison of the Truog-P and Mehlich III-P in Table 7 with the data in Table 5 indicates that they are very close to the sum of $\mathrm{Ca}_{2}-\mathrm{P}$ and $\mathrm{Ca}_{8}-\mathrm{P}$. This is clearly seen from Fig. 1. These results and the foregoing discussion on the presence of calcium phosphate suggest that the major extraction mechanism of Truog and Mehlich III method in the present soil samples is the acid-mediated dissolution of calcium phosphates. In view of simplicity of the extracting reagent, the Truog method seems better and reasonable for these soil samples. The Olsen method extracted approximately $20 \%$ of calcium phosphates. In an experiment of the various $\mathrm{P}$ rates with and without liming on a same soil, Curtin and Syers (2001) stated that liming decrease the available Olsen $\mathrm{P}$ value with the effect being largest at the highest rate of $\mathrm{P}$ addition. Liming also tended to decrease water soluble P.

Water and $\mathrm{CaCl}_{2}$ extractions gave almost identical results irrespective of different soil to water ratio, i. e.,

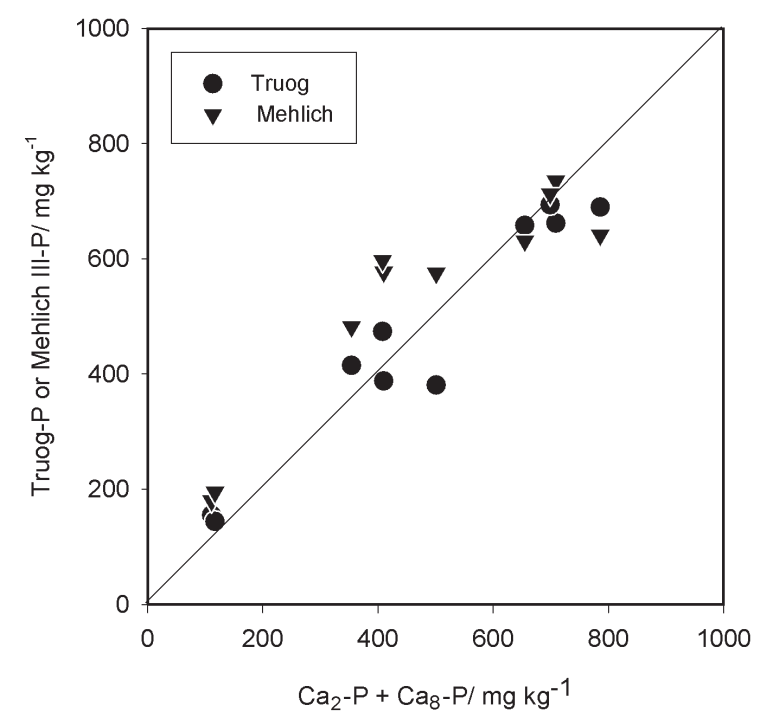

Fig. 1. Plot of Truog-P or Mehlich III-P versus $\mathrm{Ca}_{2} \mathrm{P}$ plus $\mathrm{Ca}_{8}-\mathrm{P}$ from method A.
1:5 and $1: 10$ in the water extraction and $\mathrm{CaCl}_{2}$ extraction, respectively. In the extraction with non-buffered, non-complex forming solutions, solution P concentration is governed by the solubility of existing phosphate minerals and higher amount of soluble $\mathrm{P}$ is expected in the extraction at wider soil to water ratio. The present results (Table 7) may be due to the mutual cancellation of the lower soil to water ratio and the suppression of calcium phosphate dissolution by increased Ca ion activity.

Oshima and Goto (2008) reported that the amount of $\mathrm{P}$ extracted with water at a soil to water ratio of 1:200 was highly correlated with the Truog-P with a correlation coefficient of 0.914 . They concluded that the water extraction may be useful as a mean to evaluate the amount of available phosphorus. However, their observation is not compatible with the idea that the $\mathrm{P}$ concentration in the water extract is governed by the solubility of sparingly soluble calcium phosphates like mono or dicalcium phosphate and octacalcium phosphate. The highest amount of water-extracted $\mathrm{P}$ reported by Oshima and Goto (2008) was approximately $700 \mathrm{mg}-\mathrm{P}_{2} \mathrm{O}_{5} \mathrm{~kg}^{-1}$ for a soil containing about $3500 \mathrm{mg}-\mathrm{P}_{2} \mathrm{O}_{5} \mathrm{~kg}^{-1}$ of Truog P. Since the water to soil ratio was 1:200, the $\mathrm{P}$ concentration in the extract is calculated to be about $0.05 \mathrm{mmol} \mathrm{L}^{-1}$. This concentration seems too low for the soil containing $3500 \mathrm{mg}-\mathrm{P}_{2} \mathrm{O}_{5} \mathrm{~kg}^{-1}$ of Truog $\mathrm{P}$. Their extraction may have not been at dissolution equilibrium because the extraction time was only $0.5 \mathrm{~h}$ and this would be the reason why the soil having larger Truog-P gave larger water extractable P.

Halvorson and Black (1985) applied 15 to $180 \mathrm{~kg} \mathrm{ha}^{-1}$ of $\mathrm{P}$ to a field on a Williams loam (Mollisol) and monitored the Olsen-P level for 16 crop years. The Olsen-P level decreased only gradually mainly due to the uptake by crop and maintained throughout the experimental period above the initial level. This indicates that the applied $\mathrm{P}$ was preserved as calcium phosphates and released gradually depending on the soil solution condition. Since Mollisols usually receive less precipitation and contain calcium carbonate, the applied P may have been converted to dicacalcium phosphate, octacalcium phosphate etc. and preserved for the long period of time. It was earlier believed that dicalcium phosphate reverted to octacalcium phosphate and even to colloidal hydroxyl apatite and control the $\mathrm{P}$ solubility (Lehr and Brown, 1958; Larsen, 1967). In retrospect, Kurtz (1953) noted that phosphate with soils are not entirely irreversible and that for most soils the term fixation is an exaggreation. Mattingly and talibudeen (1967) suggested that the rate of $\mathrm{P}$ removal from solution by soil components in acid and neutral soils is faster than octacalcium phosphate can be formed, indicating that octacalcium phosphate, if formed, is unlikely to persist. Bache (1964) reached a similar conclusion for the stability of strengite and verisite in most soils.

The chemical conditions in Japanese greenhouses has some resemblance in that the soils are calcium saturated due to annual liming and subjected to weak leaching. In addition, large amounts of $\mathrm{Al}-\mathrm{P}$ and $\mathrm{Fe}-\mathrm{P}$ (Table 
5) indicate that the reactive surfaces of oxide, hydroxide and noncrystalline minerals are nearly saturated with phosphate. Thus, the newly applied P can be preserved as phosphate minerals like dicacalcium phosphate and octacalcium phosphate.

The data presented in Table 5 and Table 7 and the foregoing discussion suggest that the greenhouse soils used in the present study can be regarded as semi-calcareous soils and the major sources of available P are calcium phosphates like dicacalcium phosphate and octacalcium phosphate. The Truog method applied to $\mathrm{P}$-eutrophicated greenhouse soils extracts these phosphate minerals almost selectively and it is the best testing method among the five in terms of simplicity. Olsen method gives more conservative estimate for available $\mathrm{P}$ than Truog and Mehlich method. Combination of the Truog method and equilibrium water extraction will serve as a useful test scheme to evaluate extensive and intensive factors in availability of $\mathrm{P}$.

The soil test $\mathrm{P}$ values in table 7 suggested that some long term experiment with or without $\mathrm{P}$ fertilizer application for a number of cropping years until crop yield start to lower than optimum, should be carried out to establish soil P "critical value" for a given soil and farming system in order to use nonrenewable $\mathrm{P}$ resources efficiently for economically and environmentally (Syers et al., 2008).

\section{ACKNOWLDGEMENTS}

This study was supported in part by Grant in Aid for Scientific Studies from the Japanese Society for Promoting Sciences (\# 21380048).

\section{REFERENCES}

Adhami, E., M. Maftoun, A. Ronaghi, N. Karimian, J. Yasrebi and M. T. Assad 2006 Inorganic phosphorus fractionation of highly calcareous soils of Iran. Commun. Soil Sci. Plant Anal., 37: 1877-1888

Bache, B. W. 1964 Aluminium and iron phosphate studies relating to soils. J. Soil Sci., 15: 110-116

Curtin, G. and Syers, J. K. 2001 Lime-induced changes in indices of soil phosphate availability. Soil Sci. Soc. of Amer. J., 65: $147-152$

Davison, W. and H. Zhang 1994 In situ speciation measurements of trace components in natural waters using thin film gels. Natue, 367: 546-548

Editorial Boards of Methods for Soil Environment Analysis 1997 Methods for Soil Environment Analysis, Hakuyusha (Japan)

Halvorson, A. D. and A. L. Black 1985 Long-term dryland crop responses to residual phosphorus fertilizer. Soil Sci. Soc. Am. J., 49: 928-933

Kurtz, L. T. 1953 Phosphorus in acid and neutral soils. American Society of Agronomy, 4: 59-85

Kuo, S. 1996 Phosphorus. In "Methods of Soil Analysis. Part 3 Chemical Methods", ed. By D. L. Sparks, Soil Sci. Soc. Amer. Inc., (USA), pp. 869-917

Larsen, S. 1952 The use of ${ }^{32} \mathrm{P}$ in studies on the uptake of phosphorus by plants. Plant Soil, 4: 1-10

Larsen, S. 1967 soil phosphorus. Adv. Agron., 19: 151-210

Lehr, J. R. and W. E. Brown 1958 Calcium phosphate fertilizers: II. A petrographic study of their alteration in soil. Soil sci soc. of Amer. J., 22: 29-32

Mattingly, G. E. G. \& Talibudeen, O. 1967 Progress in the chemistry of fertilizer and soil phosphorus. Volume 4. New York, Interscience, 4: 157-290

Menon, R. G., L. L. Hammond and H. A. Sissingh 1989 Determination of plant-available phosphorus by iron hydroxide impregnated filter-paper (Pi) soil test. Soil Sci. Soc. of Amer. J., 53: 110-115

Menzies N. W., B. Kusumo, and P. W. Moody 2005 Assessment of $\mathrm{P}$ availability in heavily fertilized soils using the diffusive gradient in thin films (DGT) technique. Plant Soil, $\mathbf{2 6 9}$ $1-9$

Ohoshma, H., I. Goto 2008 Accumulation of phosphate in greenhouse soils planted with small fruited watermelon in Ibaraki. Jpn. J. Soil Sci. Plant Nutr., 79: 263-271

Olsen, S. R. and L. E. Sommers 1982 Phosphorus. In "Methods of Soil Analysis. Part 2. Chemical and Microbiological Properties" ed. By A. L. Page, Soil Sci. Soc. Amer. Inc. (USA), pp. 403-430

Saarela, I. 1992 A simple diffusion test for soil-phosphorus availability. Plant Soil, 147: 115-126

Sims, J. T. 2000 Methods of soil phosphorus analysis for sediments, residuals, and waters. In "Southern Corporative Series Bulletin \#396" ed. By G. M. Pierzynski, North Carolina State Univ. (USA), pp. 17-19

Syers, J. K., A. E. Johnston and D. Curtin 2008 Efficiency of soil and fertilizer phosphorus use. FAO fertilizer and plant nutrition bulletin 18: 1-23

Than, A. A., M. Araki, Y. Suefusa and S. -I. Wada 2010 Mineralogy and chemistry of calcium phosphates in some soils under intensive cultivation. Soil Sci. Plant Nutr. submitted.

Than, A. A., K. Shoji, and S. -I. Wada, 2010 Determination of carbonate content of soils and clays by using $\mathrm{CO}_{2}$ detector tube - Improvement of the method and some applications Clay Sci., 14: 141-146.

Than A. A., K. Shoji, Y. Mori and S. -I. Wada 2009 Is pH of greenhouse soils measured adequately? J. Fac. Agr. Kyushu Univ., 54: 499-503

Thomas, G. W. and D. E. Peaslee 1973 Testing soils for phosphorus. In "Soil Testing and Plant Analysis", ed. by L. M. Walsh and J. D. Beaton, Soil Sci. Soc. Am., Madison, Wisconsin, pp. 115-132

Van der Zee, S. E. A. T. M., L. G. J. Fokkink and W. H. Van Riemsdijk 1987 A new technique for assessment of reversibly adsorbed phosphate. Soil Sci. Soc. Amer. J., 51: 599604 